\title{
Human erythroid progenitors from adult bone marrow and cord blood in optimized liquid culture systems respectively maintained adult and neonatal characteristics of globin gene expression
}

\author{
XIN ZHANG, YAN-NI MA and JUN-WU ZHANG*
}

National Laboratory of Medical Molecular Biology, Institute of Basic Medical Sciences, The Chinese Academy of Medical Sciences and The Peking Union Medical College, 5 Dong Dan San Tiao, Beijing 100005, People's Republic of China

\begin{abstract}
In vitro suspension culture procedures for erythroid progenitor cells make it possible for us to obtain large cultures of erythrocyte populations for the investigation of globin gene switching. In this study we aimed to establish optimized culture systems for neonatal and adult erythroblasts and to explore the globin expression patterns in these culture systems. To culture $\mathrm{CD} 34^{+}$cells purified from human umbilical cord blood (CB) and adult bone marrow $(\mathrm{BM})$, we respectively replaced the fetal bovine serum (FBS) with human cord serum and human adult serum. These CD $34^{+}$cells were then induced to erythroid differentiation. All the globin mRNA (including $\alpha_{-}, \zeta_{-}, \beta-, \gamma$-and $\varepsilon$-globin), the hemoglobin $(\mathrm{Hb})$-producing erythroid cells and the cellular distribution of fetal hemoglobin ( $\mathrm{Hb} \mathrm{F}$ ) were identified during the culture process. The results showed that the globin expression pattern during erythroid differentiation in our culture systems closely recapitulated neonatal and adult patterns of globin expression in vivo, suggesting that our specially optimized culture systems not only overcame the higher $\mathrm{Hb}$ F levels in the BM-derived CD34 ${ }^{+}$culture in FBS-containing medium but also eliminated the disadvantages of low cell proliferation rate and low globin mRNA levels in serum-free medium.
\end{abstract}

Key terms: adult bone marrow, cord blood, erythroid progenitor, globins, liquid culture

\section{INTRODUCTION}

The expression of human globin genes is stringently erythroid development specific. During ontogeny, the expression of $\alpha$-like globin gene displays an embryonic ( $\zeta$-) to adult $(\alpha-)$ globin switch, whereas the $\beta$-like globin gene expression displays two switches: the embryonic $(\varepsilon-)$ to fetal globin $(\gamma-)$ switch coinciding with the transition from embryonic (yolk sac) to definitive (fetal liver) hematopoiesis, and the fetal to adult $(\beta-)$ globin switch, occurring near the perinatal period concomitantly with the establishment of the bone marrow as the main site of hematopoiesis (Stamatoyannopoulos and Grosveld, 2001).
It was found that the fetal hemoglobin expression can be reactivated during adult erythropoiesis under several inherited and acquired conditions and the increased production of fetal hemoglobin can ameliorate the clinical severity of sickle cell anemia SCD and $\beta$-thalassemia (Stamatoyannopoulos and Grosveld, 2001; Rodgers and Rachmilewitz, 1995). However, as the basis in developing effective treatments for hemoglobinopathies, the understanding of developmental globin gene regulation, especially the mechanisms of globin gene switching, still remains unclear. Various in vivo and in vitro experimental systems, including cell culture, transgenic mice, somatic cell hybrids, etc., have been

\footnotetext{
* Correspondence: Prof. Jun-Wu Zhang, National Laboratory of Medical Molecular Biology, Institute of Basic Medical Sciences, Chinese Academy of Medical Sciences and Peking Union Medical College, Beijing 100005, P.R China. Phone: International +86-10-65296423. Fax: 86-10-65240529. E-mail: junwu_zhang@pumc.edu.cn X.Z and Y-N.M contributed equally to the work.
} 
used to investigate the regulation of developmental globin gene switching. In addition, the establishment of in vitro liquid culture procedure of erythroid progenitors provides us a useful tool for studying erythropoiesis on a cellular and molecular level (Fibach et al., 1989; Fibach 1998; Pope et al., 2000 ).

Different patterns of globin gene expression in cultured erythroid cells from various ontogenic stages have been reported, which were significantly influenced by culture conditions. In previous studies, FBS-containing medium was generally applied. Erythroid progenitors from adult $\mathrm{BM}$ or peripheral blood (PB) cultured in FBS-containing medium produce significantly higher $\mathrm{Hb} F$ levels than those from the circulation of donors. This might disturb our understanding of precise mechanisms of globin switching (Stamatoyannopoulos and Papayannopoulou, 1981; Alter et al., 1983; Dalyot et al., 1992). Erythroid cell culture methods using FBS-free medium had been reported, in which the levels of $\gamma$-globin and $\mathrm{F}$ cell in matured erythrocytes were similar to those in vivo (Eliason, 1986; Gabbianelli et al., 2000).

To establish and evaluate in vitro liquid culture procedures for erythroid progenitor cells to more closely represent the in vivo situation, we purified the $\mathrm{CD} 34^{+}$ hematopoietic progenitor cells (HPCs) from human umbilical cord blood (CB) and normal adult bone marrow (BM). Then $\mathrm{CD}_{3} 4^{+}$cells from $\mathrm{CB}$ and adult $\mathrm{BM}$ were cultured in optimized human cord serum (CHS)-containing and human adult serum (AHS)-containing medium. As a control, we cultured adult BM-derived CD34 ${ }^{+}$HPCs in serum-free medium (Eliason, 1986). The $\alpha$ like and $\beta$-like globin (including $\alpha-, \zeta-, \beta$-, $\gamma$-and $\varepsilon$-globin) mRNA in maturing erythroid cells were measured at different time points by real-time quantitative PCR. The kinetics of hemoglobin-producing cell number during the culture period and $F$ cell percentages in terminal cultures were also determined. We found that the kinetics of globin gene expression in $\mathrm{CB}$-derived $\mathrm{CHS}^{+}$erythroid cultures differed from those in two kinds of adult BM-derived erythroid cultures but they were very similar to the neonatal and adult kinetics of globin gene expression in vivo respectively, suggesting that the globin gene expression in neonatal and adult erythroid progenitors cultured in our optimized liquid culture systems recapitulated the expression patterns of their corresponding ontogenic stage in vivo. Furthermore, this two culture systems showed predominance in cell amplification efficiency and globin gene expression when compared to the serum-free culture.

METHODS

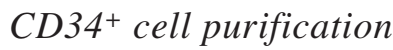

After informed consent, four umbilical cord blood (CB) samples (40 to $50 \mathrm{ml}$ each) from normal full-term deliveries and four BM samples (5 to $10 \mathrm{ml}$ each) from healthy adult donors were collected with the anticoagulant EDTA. All CB samples were diluted 1:4 with phosphate buffered saline (PBS) containing 2mM EDTA and $0.5 \%$ Bovine Serum Albumin (BSA, Sigma, St. Louis, MO, USA) for further use. To release the cells, the BM samples were diluted 10 fold in RPMI 1640 (Gibco, Invitrogen, Grand Island, NY, USA) containing 0.02\% collagenase B and $100 \mathrm{U} / \mathrm{ml}$ DNase (Sigma, St. Louis, MO, USA) and incubated at room temperature for $45 \mathrm{~min}$. Mononuclear cells (MNCs) were isolated from the diluted $\mathrm{CB}$ and $\mathrm{BM}$ by centrifugation on a gradient of Ficoll-Hypaque (density $1.077 \mathrm{~g} / \mathrm{ml}$, Sigma, St. Louis, MO, USA) (Boyum and Scand, 1968). Then CD34+ HPCs were purified by positive selection using Mini-MACS columns according to the manufacturer's protocol (Milternyi Biotech, Germany) and the purity of $\mathrm{CD} 4^{+}$cells was determined (>90\%).

\section{Cell culture}

Three kinds of liquid culture systems were established. The first one is for CB-derived $\mathrm{CD} 4^{+}$cell culture. CD34+ ${ }^{+}$HPCs purified from $\mathrm{CB}$ were cultured in Iscove's modified Dulbecco's medium (IMDM, Gibco, Invitrogen, Grand Island, NY, USA) 
containing $1 \%$ deionized bovine serum albumin (BSA, fraction V, Sigma, St. Louis, MO, USA), 30\% human cord serum (CHS, prepared by ourselves), $1 \times 10^{-5} \mathrm{M}$ dexamethasone, $100 \mu \mathrm{g} / \mathrm{ml}$ iron-saturated human transferrin, $1 \times 10^{-5} \mathrm{~mol} / \mathrm{L} \quad 2$ mercaptoethanol, $2 \times 10^{-3} \mathrm{~mol} / \mathrm{L}$ L-glutamine (all purchased from Sigma Chemical, St. Louis, MO, USA), antibiotics (Gibco, Invitrogen, Grand Island, NY, USA) and cytokines including $3 \mathrm{IU} / \mathrm{ml}$ Epo, $0.001 \mathrm{ng} /$ $\mathrm{ml} \mathrm{GM-CSF}$ and $0.01 \mathrm{U} / \mathrm{ml}$ IL-3 (R\&D System, Minneapolis, MN. USA). CD34+ cells from adult $\mathrm{BM}$ were cultured in similar medium as the CD $34^{+}$HPCs mentioned above but the $30 \%$ human adult AB-type serum (AHS, TBD, Tianjin, P R China) substituted for $30 \%$ CHS. CD34+ cells from adult $\mathrm{BM}$ were cultured in IMDM containing $1 \%$ deionized BSA (Fraction V), $10 \mu \mathrm{g} / \mathrm{ml}$ insulin, $500 \mu \mathrm{g} / \mathrm{ml}$ fully iron-saturated human transferrin, a rare inorganic element supplemented with $4 \times 10^{-8} \mathrm{~mol} / \mathrm{L}$ iron sulfate (Eliason et al., 1986), nucleotides $(10 \mu \mathrm{g} / \mathrm{ml}$ of each), $40 \mu \mathrm{g} / \mathrm{ml}$ human low-density lipoproteins (all from Sigma Chemical, St. Louis, MO, USA). The cytokine combinations and the other components added are the same as that of CHS-containing medium.

All CD34+ cells were seeded at $1 \times 10^{5}$ cells $/ \mathrm{ml}$ in $6 \mathrm{ml}$ cultures and incubated in a humidified atmosphere at $37^{\circ} \mathrm{C}$ and $5 \%$ $\mathrm{CO}_{2}$ for three weeks. Cell samples were collected from cultures on days $1,3,5,7,9$, 11,13 and 15 and stored at $-80^{\circ} \mathrm{C}$ for further use. Hemoglobin-containing erythroid cells at the different time points were identified by benzidine staining and counted in a hemocytometer in triplicates (Orkin et al., 1975).

\section{Quantitative real-time PCR assay}

Total RNA was extracted from cell samples harvested at different time points using TRIzol reagent (Invitrogen, Carlsbad, CA, USA) and quantified. Traces of DNA were removed by treatment with 5 units of DNase I (Promega, Madison, WI, USA) at $37{ }^{\circ} \mathrm{C}$ for $45 \mathrm{~min}$ followed by inactivation at $65^{\circ} \mathrm{C}$ for $10 \mathrm{~min}$. Then first-strand of cDNA was synthesized using Superscript ${ }^{\mathrm{TM}}$ III reverse transcriptase (Invitrogen, Carlsbad, CA, USA) according to the manufacturer's instruction with gene-specific primers for GAPDH, $\alpha-, \beta-, \gamma-\varepsilon$ - and $\zeta$-globin genes designed with the Primer Express (Applied Biosystems, Foster City, CA) software Version 2.0 (Table 1) (Kociok et al., 2002). All PCR products were cloned into pMD18$\mathrm{T}$ vector (Takara, Dalian, $\mathrm{P} \mathrm{R}$ China). Confirmed recombinant DNA plasmids were diluted ranging from $1: 10^{2}$ to $1: 10^{7}$ to be used to generate the standard curve for quantification. The mRNA expression level of target genes in cultured erythroid cells was quantified by real-time PCR analysis on ABI PRISM ${ }^{\circledR} 7500$ real-time PCR System (Applied Biosystems, Foster City, CA, USA) with the SYBR ${ }^{\circledR}$ Premix Ex Taq ${ }^{\mathrm{TM}}$ kit (Takara, Dalian, P R China). The following PCR cycle parameters were used: $95^{\circ} \mathrm{C}$ for $10 \mathrm{~s}, 45$ cycles at $95^{\circ} \mathrm{C}$ for $5 \mathrm{~s}$, and $60^{\circ} \mathrm{C}$ for $34 \mathrm{~s}$. Each PCR reaction was performed in triplex tubes with GAPDH as an internal control. The quantification data were analyzed with the sequence detection system (SDS) software (Applied Biosystems) and a fractional cycle number at which a threshold fluorescence was obtained (threshold cycle, $\mathrm{C}_{\mathrm{T}}$ ) for each analyzed gene with GAPDH as the reference. Standard curves were prepared based on accurately determined dilutions of plasmids containing cDNA of globins as a template. For all standard curves, the linear correlation coefficients were $\mathrm{R}^{2} \geq 0.99$. The comparative $\mathrm{C}_{\mathrm{T}}$ method was used for quantification of the target genes relative to GAPDH.

\section{Immunofluorescence staining and flow cytometry for F cells}

Cells harvested on day 18 were cytocentrifuged on a glass slide, fixed for 5 min with acetone-methanol $(9: 1, \mathrm{vol} / \mathrm{vol})$ at room temperature, washed 3 times with PBS, once with PBS containing $2 \mathrm{mg} / \mathrm{mL}$ bovine serum albumin (BSA) and incubated for 40 minutes at $37^{\circ} \mathrm{C}$ with a $1: 40$ dilution of sheep anti-human $\mathrm{HbF}$ antibodies (Bethyl Laboratories, Montgomery, TX, USA). The slides were washed twice with PBS, once with PBS/BSA, incubated for 30 minutes at room temperature with a 1:100 
dilution of the secondary FITC-conjugated mouse anti-sheep IgG (Bethyl Laboratories, Montgomery, TX, USA), and extensively washed in PBS. The slides were then mounted in DABCO (Sigma, St. Louis, MO, USA) and observed under a Nikon microscope (Nikon, Tokyo, Japan) equipped for fluorescence. Erythroid cells from $\mathrm{CB}$ and normal adult peripheral blood were used as control and processed in the same manner.

To measure the $\mathrm{F}$ cell distribution with respect to fluorescence, cells collected on day 18 were also stained as follow: cells were washed twice with PBS and resuspended. $2 \times 10^{5}$ cells were fixed for 15 min with $80 \%$ cold acetone at $4^{\circ} \mathrm{C}$. Cells were subsequently washed twice and preblocked with $2 \%$ BSA for $15 \mathrm{~min}$. Then cells were resuspended in PBS containing sheep anti-human $\mathrm{HbF}$ antibodies (Bethyl Laboratories, Montgomery, TX, USA) and incubated for $1 \mathrm{~h}$ at $37^{\circ} \mathrm{C}$. They were subsequently washed three times with PBS and incubated with the secondary FITCconjugated mouse anti-sheep IgG (Bethyl Laboratories, Montgomery, TX, USA) in 1:100 dilutions for $30 \mathrm{~min}$ at room temperature. Cells were then washed twice with PBS and at least 10,000 cells were analyzed using an Elite cytometer (Coulter, Miami, FL, USA). Green fluorescence derived from FITC was measured using a $525 \mathrm{~nm}$ bandpass filter. Erythrocytes from human $\mathrm{CB}$ and normal adult peripheral blood were also used as controls.

\section{Statistical analysis}

Statistical analysis was performed using Student's paired $t$ test, $p$ values less than 0.05 were considered to be significant. All data were expressed as mean \pm S.E, and statistical analyses were performed by SPSS version 10.0.

\section{RESULTS}

Hemoglobin accumulation during adult and neonatal erythroid maturation

CD34 ${ }^{+}$HPCs from human umbilical CB and adult $\mathrm{BM}$ were induced to erythroid differentiation for 3 weeks. The former was in CHS-containing culture system, the latter in AHS-containing and serum-free culture systems. Hemoglobin-containing erythroid cells were verified and counted by acidbenzidine staining (Figure 1). Positive cells were first observed on day 5 in both neonatal and adult erythroid cultures. The percentage of benzidine-positive cells in the three kinds of cultures increased from $6 \%$ $10 \%$ on day 5 up to $90 \%-94 \%$ on day 15 , which were very close to each other (Figure 1A). The benzidine-positive cell number was also scored in a hemocytometer at different time points and the results showed that the positive cell counts remained relatively low until day 7 . A rapid rise in $\mathrm{Hb}$-containing cell number was observed on days 9 and 11 both in neonatal and adult

TABLE 1

Gene-specific Oligonucleotide primer sets for real-time PCR

\begin{tabular}{llc}
\hline Gene & Primer Sequence 5'-3' & Product Size (bp) \\
\hline$\gamma$-globin & TGG GTC ATT TCA CAG AGG AGT TG / ATG GCA GAG GCA GAG GA & 166 \\
$\beta$-globin & GTC TAC CCT TGG ACC CAG AGG TTC / TGA GCC AGG CCA TCA CTA AAG & 131 \\
$\varepsilon$-globin & CAG CTG CAA TCA CTA GCA AGC / AGA CGA CAG GTT TCC AAA GC & 190 \\
$\alpha$-globin & GGT CAA CTT CAA GCT CCT AAG C / GCT CAC AGA AGC CAG GAA CTT G & 116 \\
$\xi$-globin & TGA GCG AGC TGC ACG CCT AC / GTA CTT CTC GGT CAG GAC AGA & 173 \\
GAPDH & TCA ACG ACC ACT TTG TCA AGC TCA / GCT GGT GGT CCA GGG GTC TTA CT & 119 \\
\hline
\end{tabular}


A
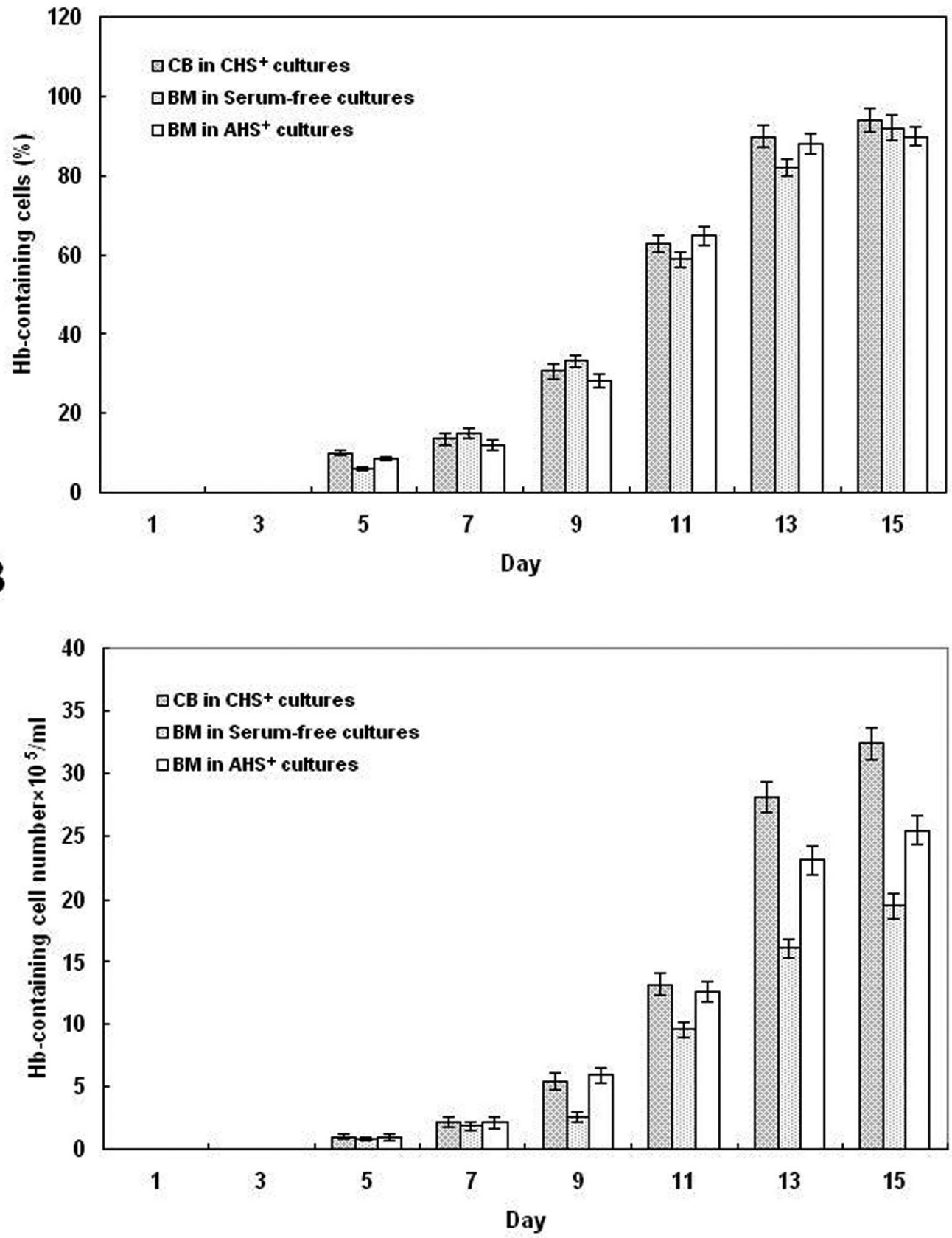

Figure 1: Hb-containing cells in maturing erythroid cells at different time points in cultures.

(A) Benzidine-positive cell percentage of maturing erythroid cells at different time points. Hbcontaining cells were observed on day 5 in both neonatal and adult cultures and the percentages of benzidine-positive cells in the three kinds of cultures all peaked on day 15 and the ultimate percentage reached $94 \%$ in neonatal, $92 \%$ in adult serum-free cultures and $90.2 \%$ in $\mathrm{AHS}^{+}$cultures, respectively. (B) Benzidine positive cell counts at different time points. Positive cell counts in serum-free erythroid cultures from adult $\mathrm{BM}$ increased from $0.78 \times 10^{5}$ cells $/ \mathrm{ml}$ on day 5 up to $19.5 \times 10^{5}$ cells $/ \mathrm{ml}$ on day 15 ; in $\mathrm{AHS}^{+}$cultures from adult BM increased from $0.96 \times 10^{5} \mathrm{cells} / \mathrm{ml}$ on day 5 up to $25.5 \times 10^{5}$ cells $/ \mathrm{ml}$ on day 15 ; in CB-derived cells, positive cell counts increase from $0.98 \times 10^{5}$ cells $/ \mathrm{ml}$ on day 5 up to $32.4 \times 10^{5}$ cells $/ \mathrm{ml}$ on day 15 . 
erythroid cultures. Positive cell counts increased from $0.78 \times 10^{5}$ cells $/ \mathrm{ml}$ on day 5 up to $19.5 \times 10^{5}$ cells $/ \mathrm{ml}$ on day 15 in adultderived serum-free cultures and from $0.96 \times 10^{5}$ cells $/ \mathrm{ml}$ on day 5 up to $25.5 \times 10^{5}$ cells/ml on day 15 in adult-derived $\mathrm{AHS}^{+}$ cultures, whereas in $\mathrm{CB}$-derived $\mathrm{CHS}^{+}$ cultures, positive cell counts increase from $0.98 \times 10^{5}$ cells $/ \mathrm{ml}$ on day 5 up to $32.4 \times 10^{5}$ cells/ml on day 15 (Figure 1B). These results suggested that the cell proliferation rate was the highest in the CB-derived $\mathrm{CHS}^{+}$culture and the lowest in the BMderived serum-free culture.

\section{Analysis of adult and neonatal kinetics of $\alpha$-like globin gene expression}

The levels of $\alpha$ - and $\zeta$-globin mRNA at different time points were determined by quantitative real-time PCR (Figure 2). In two kinds of adult BM-derived erythroid cultures (Figure 2A, B), the kinetics of $\alpha$ like globin gene expression is very similar to each other. The $\alpha$-globin mRNA levels were all peaked on day 3 , whereas the $\zeta$ globin mRNA was never detected throughout the whole erythroid maturation process both in serum-free cultures and $\mathrm{AHS}^{+}$cultures.

In erythroid cells from $\mathrm{CB}$ cultured in CHS-containing medium (Figure 2C), high level of embryonic $\zeta$-globin mRNA was detected during the early phase and it rapidly decreased from day 3 and became undetectable after day 7 . In contrast, the $\alpha$ globin mRNA level was very low at the beginning of culture period, then increased from day 3 and reached its maximal level of expression on day 13. Obviously, the kinetics of $\alpha$-like globin expression in neonatal erythroid cells displayed an embryonic $\left(\xi_{-}\right)$to adult $(\alpha-)$ globin switching when cultured in CHS-containing medium.

Analysis of adult and neonatal kinetics of $\beta$-like globin gene expression

The expressions of three $\beta$-like globin genes, including $\beta$-, $\gamma$ - and $\varepsilon$-globin gene, were also measured by quantitative realtime PCR. Our results showed that the $\beta$ - globin gene expression in the three kinds of cultures share a similar pattern (Figure 3). The $\beta$-globin mRNA remained at relatively low levels until day 9 , then rapidly increased and peaked on day 13. The $\gamma$-and $\varepsilon$-globin gene expression in two kinds of adult BM-derived erythroid cultures also shared similar patterns (Figure 3A, B), which were very different from the gene expression in neonatal erythroid cultures. The $\varepsilon$-globin mRNA was always undetectable and $\gamma$-globin expression was at highest level in the early phase, then rapidly decreased and stabilized at very low level. In $\mathrm{CB}$-derived $\mathrm{CHS}^{+}$cultures (Figure $3 \mathrm{C})$, the $\gamma$-globin mRNA increased from the beginning of culture period and reached its highest level on day 7. An abrupt rise in embryonic $\varepsilon$-globin mRNA was detected between day 1 and day 3 and then the $\varepsilon$ globin mRNA slowly decreased and remained at relatively low level.

The ratio of $\gamma / \gamma+\beta$ was calculated from directly measured mRNA levels at different time points and the kinetics of the ratio during the culture period was shown in Figure 4. It was found that in BM-derived $\mathrm{AHS}^{+}$cultures, the ratio of $\gamma / \gamma+\beta$ mRNA was very high at $92.4 \%$ in the early phase, then decreased to $4.3 \%$ on day 15 (Figure $4 \mathrm{~A})$ and it also decreased from $97.9 \%$ to $3.4 \%$ on day 15 in serum-free cultures (Figure 4B). However, the ratio of $\gamma / \gamma+\beta$ mRNA increased from $61 \%$ on day 1 up to $90 \%-91.3 \%$ on days 5 to 7 and then dropped to $57.6 \%$ on day 15 in CB-derived erythroid cells when cultured in CHScontaining medium (Figure 4C). That is, fetal $(\gamma-)$ globin was predominantly expressed since day 5 in the cultures.

Importantly, the globin mRNA levels in erythroid cells from BM cultured in serumfree medium were much lower compared to those both in neonatal and adult serumcontaining erythroid cultures although the globin gene expression pattern was very similar to that of the $\mathrm{AHS}^{+}$erythroid cultures from adult BM.

\section{F cell percentage in matured erythrocytes}

To analyze the cellular distribution of $\mathrm{Hb} \mathrm{F}$, erythroid cultures were collected on day 18 


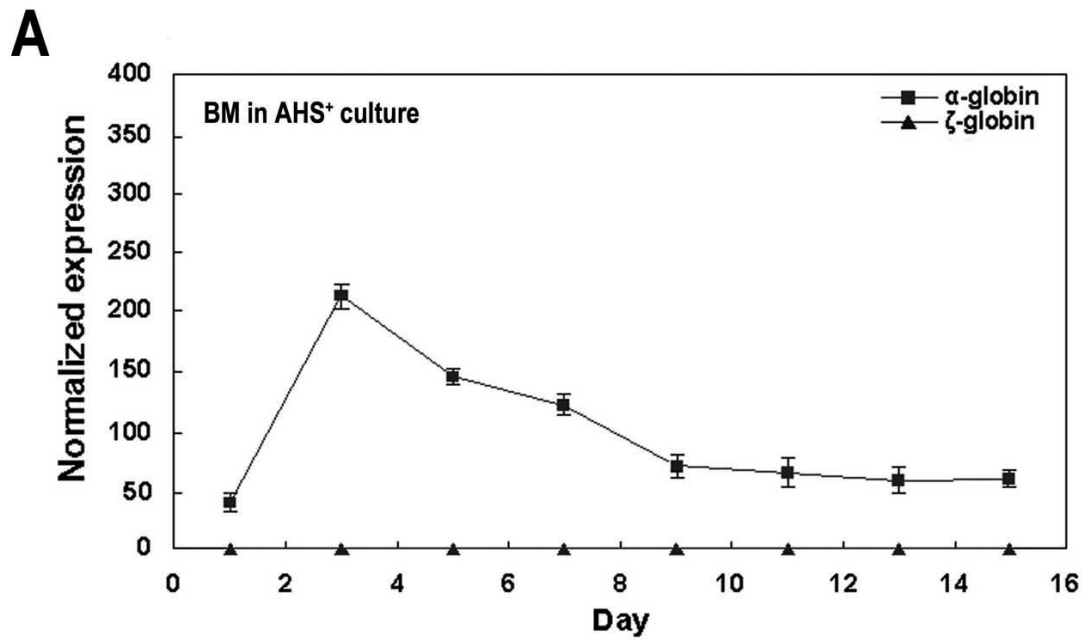

B
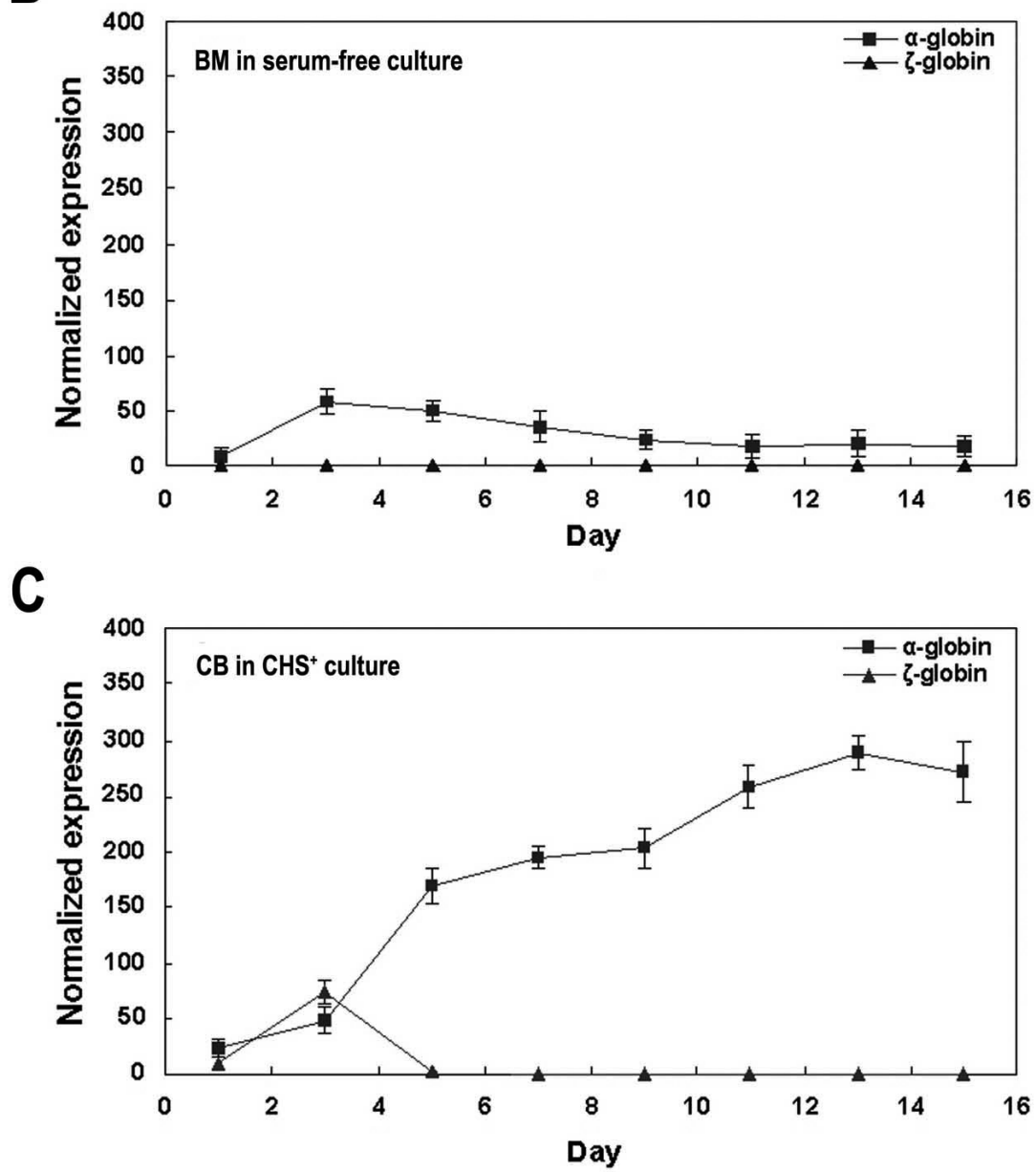

Figure 2: Kinetics of $\alpha$-like globin gene expression.

Kinetics of $\alpha$-like globin gene expression during the erythroid maturation in the adult BM-derived $\mathrm{AHS}^{+}$cultures (A), in the adult BM-derived serum-free cultures (B) and in the CB-derived $\mathrm{CHS}^{+}$ cultures (C). The $\alpha$-like globin mRNAs were detected by quantitative real-time PCR. The level of each target PCR product was normalized to that of GAPDH, an endogenous control. The $\zeta$-globin mRNA was undetectable in two kinds of adult erythroid cultures. 

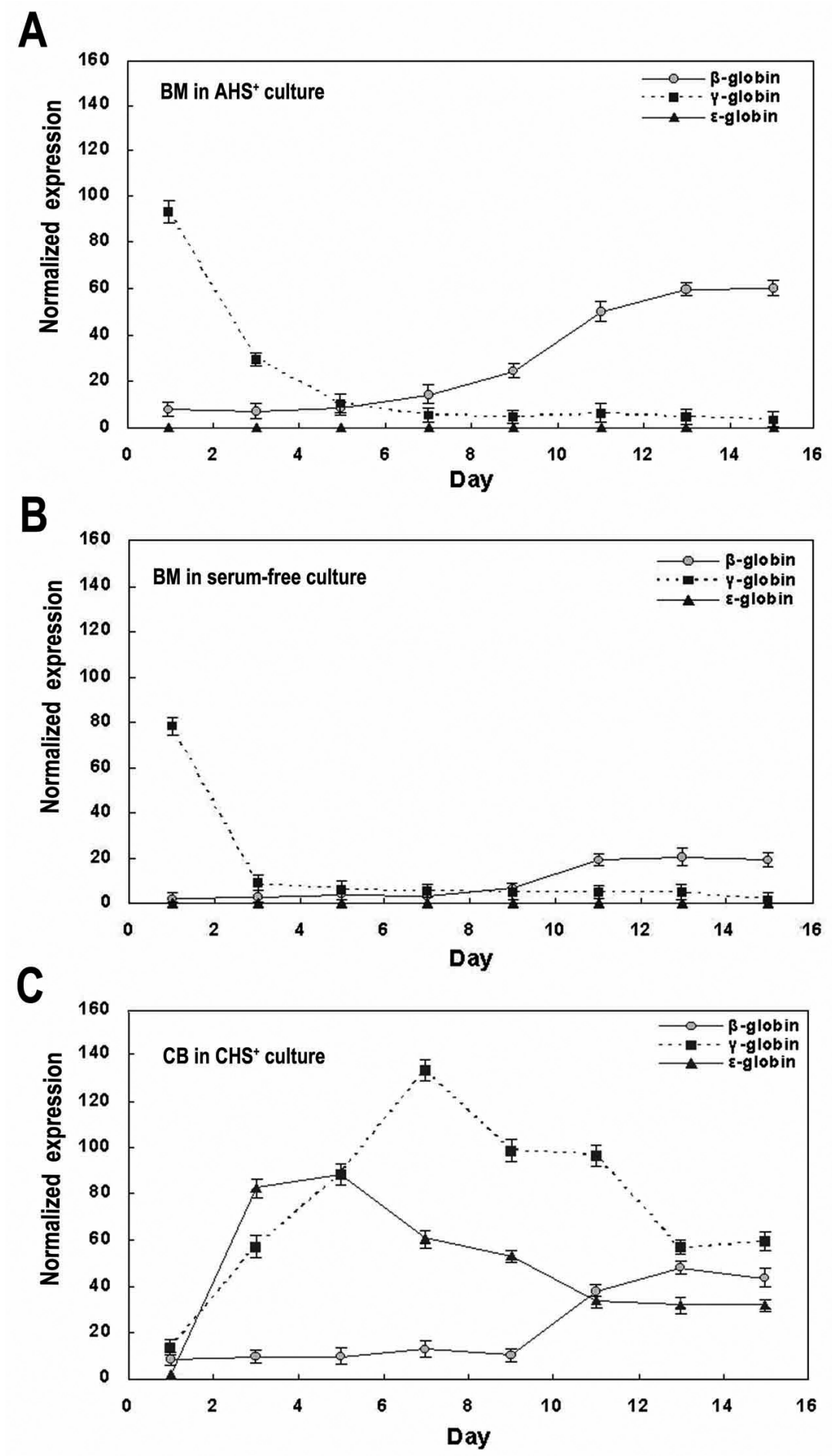

Figure 3: Kinetics of $\beta$-like globin gene expression.

Kinetics of $\beta$-like globin gene expression during the erythroid maturation in the adult BM-derived AHS-containing cultures (A), in the adult BM-derived serum-free cultures (B) and the CB-derived $\mathrm{CHS}^{+}$cultures (C). The globin mRNA levels were determined by quantitative real-time PCR. The expressions of $\beta$-and $\gamma$-globin mRNAs but not the embryonic $\varepsilon$-globin mRNA were detected in the two kinds of adult BM-derived cultures. The expressions of all of $\beta$-, $\gamma$-and $\varepsilon$-globin mRNA were detected in $\mathrm{CB}$-derived $\mathrm{CHS}^{+}$cultures. 
A

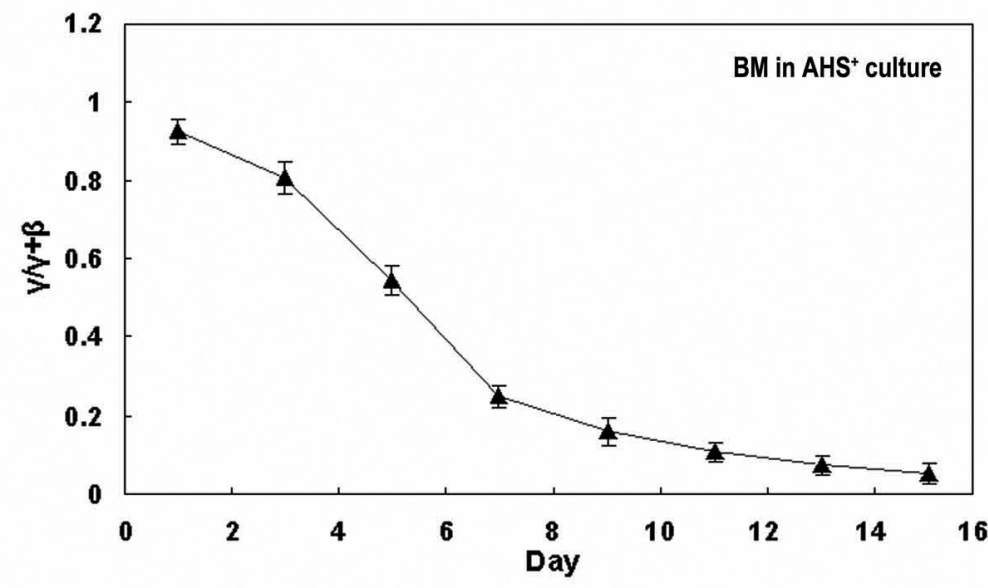

B

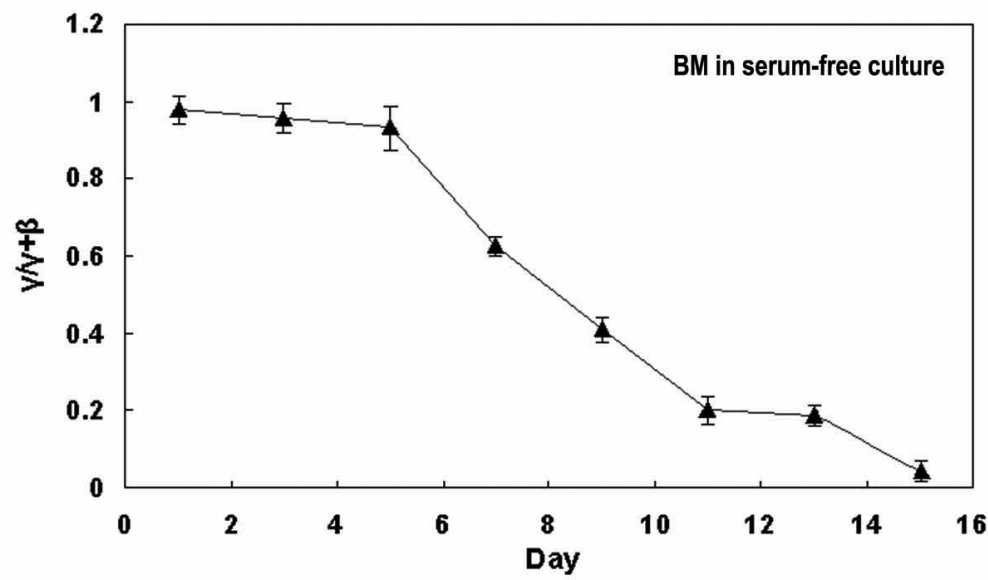

C

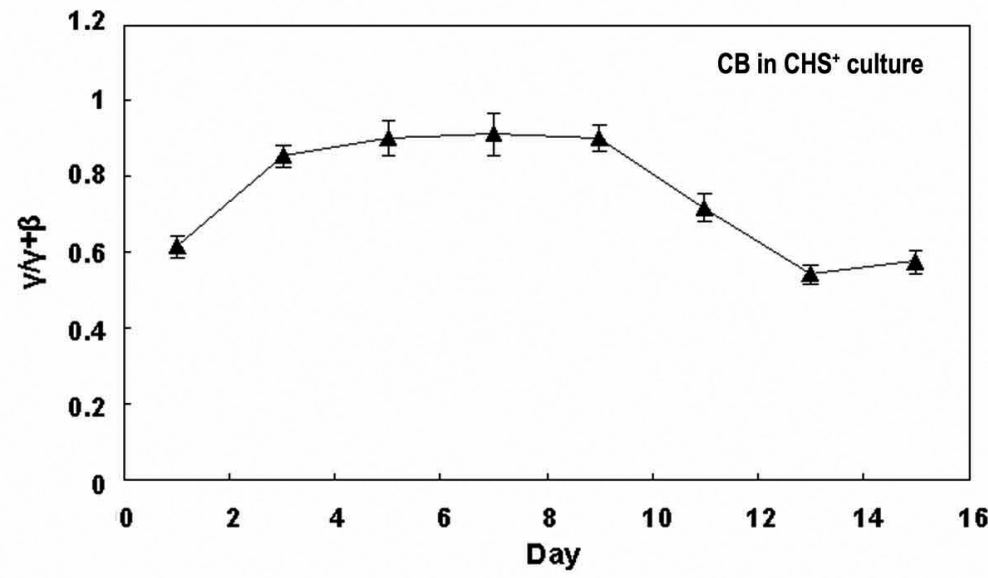

Figure 4: Kinetics of $\gamma / \gamma+\beta$ mRNA during the erythroid maturation in the cultures. The ratios were calculated from the real-time PCR in adult BM-derived $\mathrm{AHS}^{+}$cultures (A), in the adult BMderived serum-free cultures (B) and in the $\mathrm{CB}$-derived $\mathrm{CHS}^{+}$cultures $(\mathrm{C})$. The ratio in two kinds of adult erythroid cultures were very high $(92.4 \%-97.9 \%)$ in the early phase, then decreased to $3.4 \%$ in serum-free medium and $4.3 \%$ in $\mathrm{AHS}^{+}$medium on day 15 , respectively. However, in the CBderived $\mathrm{CHS}^{+}$cultures, the ratio of $\gamma / \gamma+\beta$ mRNA increased from $61 \%$ on day 1 up to $91.3 \%$ on day 7 to 9 and then dropped to $57.6 \%$ on day 15 . 
Ai
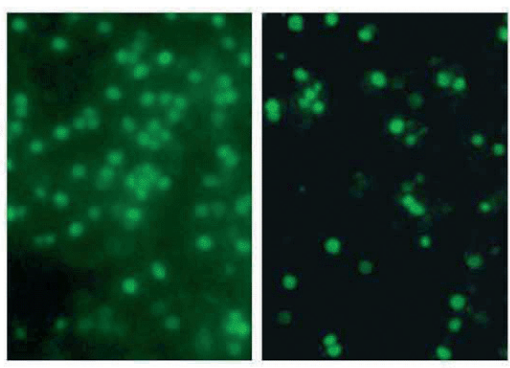

Bi
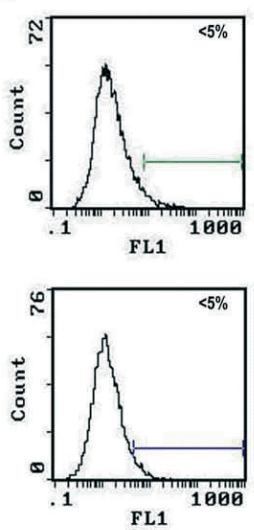

Aii
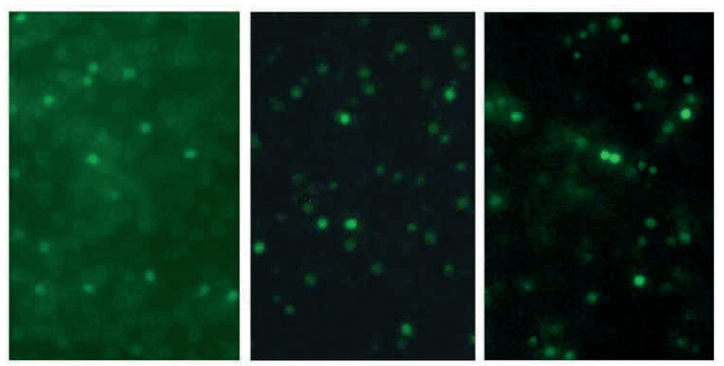

\section{Bii}
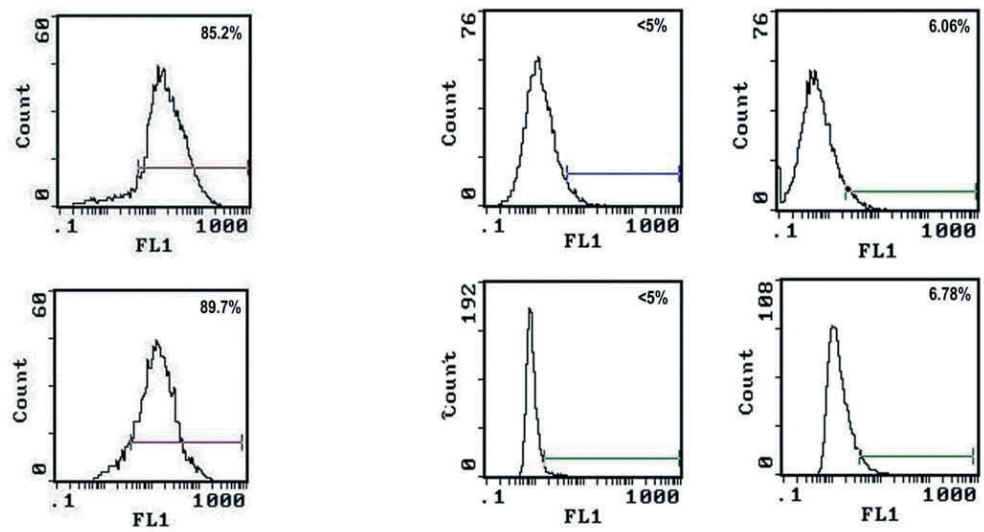
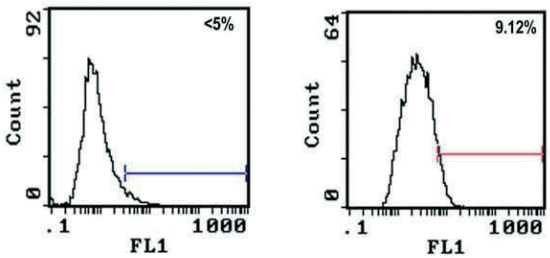

Figure 5: Immunofluorescence staining and flow cytometric analysis of $\mathrm{Hb}$ F-containing erythroid cells in cultures.

The cellular distribution of $\mathrm{Hb} \mathrm{F}$ was analyzed by Immunofluorescence staining and flow cytometry on day 18 using monoclonal antibodies directed against Hb F. (Ai left) The erythroid cells from umbilical CB were used as positive control; (Ai right) The matured erythroid cells in CB-derived $\mathrm{CHS}^{+}$cultures; (Aii left) The erythroid cells from adult peripheral blood were used as positive control; (Aii middle) the matured erythroid cells in adult BM-derived serum-free cultures; (Aii right) the matured erythroid cells in adult $\mathrm{AHS}^{+}$erythroid cultures. All the left panels of $\mathrm{Bi}$ and Bii represent the samples only labeled with the second FITC-conjugated mouse anti-sheep IgG and used as background. (Bi right) The F cell proportion of erythroid cells from umbilical CB (upper panel) and matured erythroid cells in neonatal $\mathrm{CHS}^{+}$cultures determined by flow cytometry; (Bii right) The F cell proportion of erythroid cells from adult peripheral blood (upper panel), matured adult erythroid cells cultured in serum-free medium (middle panel) and matured adult erythroid cells cultured in AHS-containing medium (bottom panel). The results showed that the proportion of F cells scored by Immunofluorescence staining under microscopy is consistent to that determined by flow cytometry. 
and determined by immunofluorescence staining and flow cytometry using monoclonal antibodies directed against $\mathrm{Hb}$ F. F cells were observed and scored under microscope equipped for fluorescence and the results showed that the proportion of $\mathrm{Hb}$ F-containing cells of the matured neonatal erythrocytes cultured in CHS-containing medium $(93 \%)$ was similar to positive control $(86.7 \%)$. It is also consistent with the results of flow cytometry (Figure 5Ai, Bi. $89.7 \%$ for cultured neonatal erythrocytes and $85.2 \%$ for positive control). In contrast, the percentage of $\mathrm{F}$ cells was very small in adult erythroid cultures. The results obtained by flow cytometry showed that the percentages of $\mathrm{F}$ cells were $9.12 \%$ (in $\mathrm{AHS}^{+}$ cultures) and $6.78 \%$ (in serum-free cultures), which were close to the positive controls (Figure 5 Aii, Bii).

These results indicated that globin gene expression in CB- and adult BM-derived erythroid progenitors under our optimized CHS- and AHS-containing culture conditions respectively reflect the physiological globin program of the neonatal and adult erythroid progenitors.

\section{DISCUSSION}

For years, the mechanisms of hemoglobin switching have become the focus of study in globin field because the understanding of these mechanisms is not only of biological significance but also relevant to the development of rational design of therapies for a variety of hemoglobinopathies, but the precise mechanisms of hemoglobin switching are still far from being demonstrated. Primary cultures of erythroid cells, especially the more recently established liquid culture procedure provides us with a very important tool for studying the regulation of globin gene expression during erythropoiesis in vitro. Compared to the cell lines, the growth of human erythroid progenitors derived from fetal liver, umbilical $\mathrm{CB}$, adult $\mathrm{BM}$ or $\mathrm{PB}$ in primary cultures represent more closely the in vivo situation (Fibach et al., 1989).

Previous data have shown that the relative $\gamma$-chain synthesis in adult-derived
$\mathrm{FBS}^{+}$erythroid cultures (10\%-20\%) was higher compared to corresponding levels (<2\%-3\%) in vivo (Papayannopoulou et al., 1977). The high background levels of $\mathrm{Hb} \mathrm{F}$ in serum-supplemented cultures might hamper our understanding of globin gene regulation. However, the $\mathrm{Hb} F$ reactivation in adult erythroid cultures is significantly diminished and the level of $\gamma$-chain synthesis is closer to that found in vivo it when cultured in serum-free medium (Gabbianelli et al., 1989; 2000).

To recapitulate the neonatal and adult patterns of globin gene expression, optimized suspension culture systems were established and applied for different erythroid progenitors here. We hoped that human $\mathrm{CB}$-and adult BM-derived erythroid progenitors cultured in our optimized CHSand AHS-containing medium could mimic the in vivo situation. Although the number of precursor cells is very low in both $\mathrm{CB}$ and $\mathrm{BM}$, the development of cell sorting technique allowed us to enrich for a sufficient number of nonhemoglobinproducing $\mathrm{CD}_{3} 4^{+}$cells. Compared with mononuclear cells (MNCs), cultured CD34+ HPCs in our study undergo a more synchronized differentiation program and avoid the presence of large nonerythroid cell populations (mainly $\mathrm{T}$ and $\mathrm{B}$ lymphocytes), which perturb the globin mRNA quantitation.

With benzidine staining procedures (Orkin et al., 1975), Hb-producing cells were determined and the results indicated that erythroid cells from umbilical $\mathrm{CB}$ and adult BM showed no difference on total hemoglobin accumulation during maturation (Figure 1A). Benzidine-positive cells were detected on day 5 in both neonatal and adult erythroid cultures and the kinetics of $\mathrm{Hb}$-containing cell percentage increase were almost the same. Furthermore, the final percentage of $\mathrm{Hb}$ producing cells was also similar to previous studies, ranging from $94.4 \%$ to $97.2 \%$ (Fibach et al.,1989; Fibach, 1998). However, it should be noted that the benzidine-positive cell number in CBderived erythroid cells cultured in CHScontaining medium increased more rapidly than adult BM-derived erythroblasts 
cultured in AHS-containing and serum-free medium. The positive cell number in neonatal cultures on day 15 is nearly 2 -fold higher than their adult culture counterparts. Early studies showed that human progenitor cells from neonatal $C B$ have greater hematopoietic expansion capacity than those from adult BM or mobilized PB (Vivek et al., 2002). So we believed that the genetic characteristics of the erythroid progenitor cells and some uncertain components in cord blood serum may act as a stimulator and be responsible for the marked differences of cell expansion capacity between neonatal and adult erythroid cells.

The quantitative real-time PCR assay provides us a more sensitive and specific assay to study changes in gene expression under various conditions and varying time points (Heid et al., 1996; Gibson et al., 1996). In this study, the kinetics of globin gene expression in neonatal and adult erythroid cultures were directly determined and characterized by quantitative real-time PCR. Embryonic ( $\left.\xi_{-}\right)$to adult $(\alpha-)$ globin switching and embryonic $(\varepsilon-)$ to fetal $(\gamma-)$ globin switching were observed in neonatal erythroid cultures, while embryonic ( $\zeta$ - and $\varepsilon-)$ globin mRNA was never detected during the adult erythroid maturation. In humans, it was reported that the $\varepsilon$-globin expression is restricted to the yolk sac cells detected by immunochemical methods and the synthesis of $\zeta$-chains can be detected in normal newborns. However, the embryonic $\zeta$ - and $\varepsilon$-globin mRNA were all detected in neonatal erythroid cultures in the present study. Based on these results, we concluded that the maturing neonatal erythroid cells cultured in $\mathrm{CHS}^{+}$medium here recapitulated the sequential globin gene expression as found during in vivo embryonic and fetal development (Papayannopoulou et al., 1983; Chui et al., 1989).

In the current study, the ratio of $\gamma / \gamma+\beta$ mRNA during the culture period showed that $\gamma$ - and $\beta$-globin were predominantly expressed in neonatal- and adult-derived erythroid cells, respectively, which were consistent with the previous reports (Bard, 1975; Papayannopoulou et al., 1977; Wood et al., 1975). The cellular distributions of $\mathrm{Hb}$ $\mathrm{F}$ in cultured erythroid cells were analyzed by immunofluorescence staining and flow cytometry in our study. In contrast to the low and similar $F$ cell percentage in adult erythroid cultures and adult PB control, the $F$ cell percentage in neonatal erythroid cultures was very high and similar to that of umbilical CB control. This confirmed our success in recapitulating the in vivo situation.

It has been reported that the erythroid progenitors from adult BM or PB cultured in a previously established FBS-containing culture system produced significantly higher $\mathrm{Hb} \mathrm{F}$ levels than were observed in the circulation of donors (Pope et al., 2000; Stamatoyannopoulos and Papayannopoulou, 1981; Alter et al., 1983). The serum-free culture system may have solved this problem (Yoshihiro et al., 1990). Here, we also cultured part of CD34+ HPCs in serumfree medium as a control. We found that the globin gene expression pattern and $\mathrm{F}$ cell percentage in adult BM-derived erythroid cells cultured in our optimized AHScontaining medium were very similar to those in serum-free cultures. However, the low cell proliferation rate and low globin mRNA level were observed in serum-free cultures. These suggested that our CBderived $\mathrm{CHS}^{+}$culture and $\mathrm{BM}$-derived $\mathrm{AHS}^{+}$culture showed advantages in cell growth and globin expression when compared with the serum-free culture.

Taken together, we developed and established CB-derived erythroid cell $\mathrm{CHS}^{+}$culture system and BM-derived erythroid cell $\mathrm{AHS}^{+}$culture in which cell growth and globin expression programs could represent the in vivo situation more closely. The culture systems we optimized for neonatal and adult erythroid cells here can provide us with an important experimental tool for studying the precise mechanisms of globin gene switching. We hope that the comparison of neonatal and adult erythroid cultures could contribute to our understanding of the precise mechanisms of globin gene switching which is crucial for development of rational design of therapies for a variety of hemoglobinopathies. 


\section{ACKNOWLEDGEMENTS}

This work is supported by the National High Technology Research and Development of China (2002AA223071) and the National Nature Science Foundation of China (30393110 and 30421003) to J. W. Zhang.

\section{REFERENCES}

ALTER BP, GOLDBERG JD, JACKSON BT, PIASECKI GJ, LIPTON JM, NATHAN DG (1983) Evidence fro a clonal model for hemoglobin switching. In: STAMATOYANNOPOULOS G, NIENHUIS (eds) Globin Gene Expression and Hematopoietic Differentiation. A.W. New York: Alan R Liss. pp: 431-441

BARD H (1975) The postnatal decline of hemoglobin $F$ synthesis in normal full-term infant. J Clin Invest 55: 395-403

BOYUM A, SCAND J (1968) Separation of leukocytes from blood and bone marrow. Scand J Clin Lab Invest 97: 7-12

CHUI DH, MENTZER WC, PATTERSON M, JAROCCI TA, EMBURY SH, PERRINE SP, MIBASHAN RS, HIGGS DR (1989) Human embryonic $\zeta$-globin chains in fetal and newborn blood. Blood 74: 6188-6194

DALYOT N, FIBACH E, RACHMILEWITZ EA, OPPENHEIM A (1992) Adult and neonatal patterns of human globin gene expression are recapitulated in liquid cultures. Exp Hematol 20: 1141-5

ELIASON J (1986) Granulocyte-macrophage colony formation in serum-free culture: Effects of purified colony-stimulating factors and modulation by hydrocortisone. J Cell Physiol 128: 231-238

FIBACH E (1998) Techniques for studying stimulation of fetal hemoglobin production in human erythroid cultures Hemoglobin 22: 445-448

FIBACH E, MANOR D, OPPENHEIM A, RACHMILEWITZ EA (1989) Proliferation and maturation of human erythroid progenitors in liquid culture. Blood 73: 100-103

GABBIANELLI M, PELOSI E, BASSANO E, LABBAYE C, PETTI S, ROCCA E, TRITARELLI E, MILLER BA, VALTIERI M, TESTA U (1989) Granulocytemacrophage colony-stimulating factor reactivates fetal hemoglobin synthesis in erythroblast clones from normal adults. Blood 74: 2657-2667

GABBIANELLI M, TESTA U, MASSA A, PELOSI E, SPOSI NM, RICCIONI R, PELOSI E, LUCHETTI L, PESCHLEC C (2000) Hemoglobin switching in unicellular erythroid culture of sibling erythroid burstforming units: kit ligand induces a dose-dependent fetal hemoglobin reactivation potentiated by sodium butyrate. Blood 95: 3555-3561

GIBSON UE, HEID CA, WILLIAMS PM (1996) A novel method for real time quantitative RT-PCR. Genome Res 10: 995-1001

HEID CA, STEVENS J, LIVAK KJ, WILLIAMS PM (1996) Real time quantitative PCR. Genome Res 6: 986-994
KOCIOK N, HUEBER A, ESSER P, SCHRAERMEYER U, THUMANN G, LUTHER TT, JORDAN J, WELSANDT G, KIRCHHOF B (2002) Vitreous Treatment of Cultured Human RPE Cells Results in Differential Expression of 10 New Genes. Invest Ophthalmol Vis Sci 43: 2474-2480

LIEBHABER SA, WANG Z, CASH FE, MONKS B, RUSSELL JE (1996) Developmental silencing of the embryonic zeta-globin gene: concerted action of the promoter and the 3'-flanking region combined with stage-specific silencing by the transcribed segment. Mol Cell Biol 16: 2637-2646

ORKIN SH, HAROSI FI, LEDER P (1975) Differentiation in erythroleukemic cells and their somatic hybrids. Proc Natl Acad Sci U S A 72: 98-102

PAPAYANNOPOULOU TH, BRICE M, STAMATOYANNOPOULOS G (1977) Hemoglobin F synthesis in vitro: evidence for control at the level of primitive erythroid stem cells. Proc Natl Acad Sci U S A 74: $2923-2927$

PAPAYANNOPOULOU TH, SHEPARD TH, STAMATOYANNOPOULOS G (1983) Studies of hemoglobin expression in erythroid cells of early human fetuses using anti- $\gamma$ and anti- $\gamma$-globin chain fluorescent antibodies. In: STAMATOYANNOPOULOS G, NIENHUIS (eds) Globin gene expression and hemopoietic differentiation. S.W. New York: Alan R Liss. pp: 421-430.

POPE SH, FIBACH E, SUN J, CHIN K, ROGERS G.P (2000) Two-phase liquid culture system models normal human adult erythropoiesis at the molecular level. Eur J Haematol 64: 292-303

RODGERS GP, RACHMILEWITZ EA (1995) Novel treatment options in the severe beta-globin disorders. Br J Haematol 91: 263-268

RUTHERFORD T, CLEGG JB, HIGGS DR, JONES RW, THOMPSON J, WEATHERALL DJ (1981) Embryonic erythroid differentiation in the human leukemic cell line K562. Proc Natl Acad Sci U S A 78: 348-352

STAMATOYANNOPOULOS G, GROSVELD F (2001) Hemoglobin switching. In: STAMATOYANNOPOULOS G, MAJERUS P, PERLMUTTER R, VARMUS H (eds) The Molecular Basis of Blood Diseases. $3^{\text {rd }}$ ed. Part II, Red Cells.. Philadelphia: W.B.Saunders Publishing Co. pp: $135-182$

STAMATOYANNOPOULOS G, PAPAYANNOPOULOU TH (1981) The switching from hemoglobin $F$ to hemoglobin A formation in man: parallels between the observations in vivo and the findings in erythroid cultures. In: BREWER GJ (eds) The red cell. Fifth Ann Arbor conference. New York: Alan R Liss. pp: 665-669

VIVEK MT, MATTHEW TM, RACHATA L (2002) Human stem-progenitor cells from neonatal cord blood have greater hematopoietic expansion capacity than those from mobilized adult blood. Exp Hematol 30 816-823

WOOD WG, STAMATOYANNOPOULOS G, LIM G, NUTE PE (1975) F-cells in the adult: normal values and levels in individuals with hereditary and acquired elevations of $\mathrm{Hb} \mathrm{F}$. Blood 5: 671-682

YOSHIHIRO F, MAKIO O, STEVEN CC, GEORGE JD (1990) Serum-free culture of the enriched hematopoietic progenitors reflects physiologic levels of fetal hemoglobin biosynthesis. Blood 75: 1718-1722 
